EGU2020-13863

https://doi.org/10.5194/egusphere-egu2020-13863

EGU General Assembly 2020

(c) Author(s) 2020. This work is distributed under

the Creative Commons Attribution 4.0 License.

\title{
A chemostratigraphic framework for the type-Maastrichtian
}

\author{
Johan Vellekoop ${ }^{1,2}$, Pim Kaskes ${ }^{2}$, Sinnesael Matthias ${ }^{2}$, John W. M. Jagt ${ }^{3}$, Robert P. Speijer ${ }^{1}$, and \\ Philippe Claeys ${ }^{2}$ \\ ${ }^{1}$ Division Geology, KU Leuven, Leuven, Belgium (johan.vellekoop@kuleuven.be) \\ ${ }^{2}$ AMGC research group, Vrije Universiteit Brussel, Brussels, Belgium \\ ${ }^{3}$ Natuurhistorisch Museum Maastricht, Maastricht, The Netherlands
}

The youngest time interval of the Cretaceous Period is known as the Maastrichtian, a reference to the marine strata exposed in the area surrounding the city of Maastricht, in the NetherlandsBelgium border region. The stratigraphic succession at the original type-locality of the Maastrichtian (ENCl quarry, NL) only covers the upper part of the Maastrichtian Stage as it is nowadays defined. However, in combination with similar rock sequences in several other quarries (e.g. Hallembaye, Curfs) in the region, a substantial part of the Maastrichtian Stage is represented.

While the type-Maastrichtian strata have provided a wealth of paleontological data, comparatively little geochemical work has been carried out on this succession. So far, the age assessment of, and stratigraphic correlation with, the type-Maastrichtian has been largely based on biostratigraphy and preliminary attempts at cyclostratigraphy, techniques that are hampered by bioprovincialism and the presence of stratigraphic gaps in the succession. In recent years, stable carbon isotope stratigraphy has been proven to be a powerful tool for correlating Upper Cretaceous strata on a global scale. When calibrated with biostratigraphic events, carbon isotope stratigraphy can be used to test the synchroneity of bio-events and reconcile inter-regional biostratigraphic schemes. Therefore, we have generated the first high-resolution stable carbon isotope stratigraphy for the type-Maastrichtian, using the extensive sample set acquired in the context of the Maastrichtian Geoheritage Project. In combination with elemental data generated using $\mu$ XRF (e.g. Ca, Si, Al, Ti, $\mathrm{Fe}$ wt\%), our record presents the first high-resolution chemostratigraphy for the typeMaastrichtian. This new chemostratigraphic framework enables us to refine the age-model for studied strata, and allows a better regional and global correlation with the type-Maastrichtian successions, placing the paleontological records from the type-Maastrichtian in a global context. 